\title{
ESTABLISHMENT OF THE ACCIDENT COMPENSATION COMMISSION 1973: ADMINISTRATIVE CHALLENGES
}

\author{
John R Martin*
}

Alongside the process of legislative review and enactment, questions of administrative structure and implementation received lively consideration. At stake were such issues as whether to treat the new scheme as a matter of law reform or an aspect of social security. ACC's eventual status as an independent commission posed challenges to public officials from several departments, while preserving certain tensions that would emerge later in the 1970s. This paper credits the New Zealand public service for its creative response to implementing ACC, which required it to bridge the structural divides and alternative conceptions of how the new scheme might work. The paper describes the pivotal decisions and persons that guided ACC into its initial decade.

The five guiding principles can be summarised as ... administrative efficiency. ${ }^{1}$

\section{INTRODUCTION}

The Accident Compensation Act 1972 became law in the last days of the National Government that had been in office since 1949 (except for the brief interregnum of the Labour Government led by Walter Nash between 1957 and 1960). These two decades were a period of marked stability in New Zealand government (although, as discussed below, the signs of the turbulence that was to follow in the 1970s and 1980s were appearing by 1967). That stability was reflected in the role of the Public Service as the principal - but not the only — adviser to ministers and the vehicle through which policy was translated into administration. In this context an examination of the

* Teaching Fellow, School of Government, Victoria University of Wellington, and one-time Assistant Secretary, The Treasury and Deputy Director-General (Administrative), Department of Health (although, in both of the latter positions his contact with the ACC was minimal). The author is grateful to Maria Crequer (State Services Commission), Fiona Staples (Treasury) and staff of National Archives for assistance in locating departmental files.

1 New Zealand Royal Commission of Inquiry into Compensation for Personal Injury Compensation for Personal Injury in New Zealand: Report of the Royal Commission of Inquiry (Government Printer, Wellington, 1967) para 4 [Woodhouse Report]. 
development of the Accident Compensation Act 1972 and the establishment of the Accident Compensation Commission (ACC) provides an informative case study of the "old" Public Service at work. ${ }^{2}$ It also raises questions about the choice of a public corporation, a quango, rather than a department as the institution through which a highly significant social policy initiative would be delivered.

This article sketches the principal features of public administration in New Zealand thirty years ago; discusses the machinery of government issues that had to be resolved before the new compensation scheme could operate; describes the administrative challenges facing those charged with implementing the Accident Compensation Act 1972; and concludes with some reflections on the processes surrounding the birth of ACC. Specifically, the article examines three propositions, namely that:

- the setting up of the accident compensation scheme, regarded at the time by ministers and officials as the largest administrative change (apart from mobilisation for war) since the Social Security Act 1938, was a considerable achievement of the "old" Public Service; ${ }^{3}$

- the ACC, once established, was something of an "institutional orphan": while there are strong claims to parentage, no department of State was keen to accept the responsibilities of guardianship; and

- relationships between the new Commission and departments, notably the central agencies, were coloured by a view that the ACC's "independence" had given it an unwarranted position of bureaucratic privilege. ${ }^{4}$

This article examines these three propositions but first it is necessary to say a little about the political and administrative context of the period between the 1960s and the mid-70s.

\section{THE CONTEXT}

A number of commentators identify 1967 as the turning point in New Zealand's post-war economic history. ${ }^{5}$ It was the year in which the currency was devalued for the first time since World

2 The "old" Public Service refers to the administrative system prior to "New Zealand's bureaucratic revolution" of the 1980s. (Jonathan Boston and others Reshaping the State: New Zealand's Bureaucratic Revolution (Oxford University Press, Auckland, 1991)).

3 There is something of a paradox here. Despite the significance of the new scheme, in both policy and administrative terms, there seems to have been very little interest outside those immediately involved and in the law. For instance, a fairly wide-ranging volume on social policy published in 1977 — Andrew D Trlin (ed) Social Welfare and New Zealand Society (Methuen, Wellington, 1977) — has no mention of the ACC.

4 "A certain amount of jealousy existed in official circles about the independence of the Commission (and to some extent its staff) in carrying out what was viewed as a public function": Ian Campbell Compensation for Personal Injury in New Zealand: Its Rise and Fall (Auckland University Press, Auckland, 1996) 48. 
War Two following a collapse in the wool price; it saw the introduction of a series of techniques to halt the growth in public expenditure, including mini-budgets and staff ceilings in government departments; for the first time since the war there were more people unemployed (over 13,000) and on work schemes than there were vacancies; there was a significant net outward migration for the first time since the depression; per capita real income fell by two per cent; the Consumer Price Index jumped by six per cent; and Robert Muldoon became Minister of Finance. ${ }^{6}$ The era of "steady does it" associated with Keith Holyoake was ending. ${ }^{7}$ More starkly, it was the "end of the golden weather". 8

And yet this was a period in which the National Government launched two Royal Commissions with the potential to expand the welfare state, broadly defined: Woodhouse in 1967 and the McCarthy Commission on Social Security in $1972 .{ }^{9}$ Personal recollections suggest that the heart of the bureaucracy these were seen as long-running rather peripheral exercises. The issues that preoccupied the "inner court" of officials in departments such as the Treasury, Trade and Industry and External Affairs were economic: increased production and diversification of the economy (the National Development Conference launched in 1968), the battle with "stagflation" built around incomes policies and price controls, and negotiations over British entry into the European Economic Community (which were on and off between 1961 and 1973).

Turning now to the administrative context, it is useful to repeat the familiar encapsulation of the "old" Public Service: it was an apolitical, anonymous, merit-based, unified, career service operating within a long-standing framework of statute and convention. The McCarthy Commission of 1962 and the State Services Act 1962 that followed did not alter these principles that had endured from the Public Service Act $1912 .{ }^{10}$ The New Zealand State services remained "bureaucratic" in the

5 See, for example, Brian Easton In Stormy Seas (University of Otago Press, Dunedin, 1997) and Gary R Hawke The Making of the New Zealand Economy (Cambridge University Press, Cambridge (UK), 1985). A short-lived commodity boom in the early 1970s has tended to obscure this turning point and too often New Zealand's long "winter of discontent" is attributed to British entry into the European Economic Community (EEC) in 1973 and the first oil shock of 1973/74. Despite the impact of these events the problems of a small, pastoral economy with high expectations were already evident in the 1960s.

6 Robert D (later Sir Robert) Muldoon was Minister of Finance between 1967 and 1972 and again between 1975 and 1984. During the second period he was also Prime Minister.

7 Keith J (later Sir Keith) Holyoake was Deputy Prime Minister, 1949-1957, briefly Prime Minister in 1957, and Prime Minister again from 1960 to 1972.

8 John Gould The Rake's Progress: The New Zealand Economy Since 1945 (Hodder and Stoughton, Auckland, 1982) 113.

9 New Zealand Royal Commission of Inquiry into Social Security "Social Security in New Zealand: Report of the Royal Commission of Inquiry" [1972] IV AJHR H 53.

10 The Royal Commission of Inquiry into the State Services in New Zealand was chaired by Thaddeus P (later Sir Thaddeus) McCarthy, Justice of the Supreme Court, and reported in June 1962 (Government Printer, Wellington, 1962). It is often referred to simply as "McCarthy". (McCarthy also chaired the 1972 Royal 
neutral, Weberian sense. In some respects McCarthy had inaugurated systems that were even more rule-bound than the arrangements previously in place: for example, in the complex wage-fixing procedures that led to some 140 occupational classes in the Public Service. ${ }^{11}$ This was the Public Service of the Public Service Manual and the Treasury Instructions and of uniform pay and conditions for the Public Servants employed by the State Services Commission (SSC). It was a Public Service that had grown from 23,000 in 1947 (when war-time temporaries were absorbed into the permanent staff) to 53,000 in 1972 when the Accident Compensation Act 1972 was passed. It is also worth noting again that between 1949 and 1972 the National Government was in office for all but three years. There was a strong sense of apolitical continuity in the relationship between ministers and officials.

Post-1984 revisionist history has not given the "old" Public Service a good press. This is not the occasion to right the balance. It is useful, however, to make two points that relate to the ACC. The first is that this case study illustrates the capacity of the Public Service to implement major projects through the application of service-wide resources. Secondly, the Public Service in the post-war period was the institution through which a great deal of "nation-building" was accomplished; outstanding public servants were among those who contributed both design and construction effort to this task. ${ }^{12}$

One aspect of this contribution is of enduring interest - the interplay between ministers and officials in initiating policy change. Kenneth J Scott in 1955 suggested that in social welfare policy "the initiative is passing from the politicians to the administrators ... Formerly the initiative was clearly with politicians ... The turning point was in the latter half of the forties". He later amended his position to say "not that the initiative is passing to the administrators, but that it will pass to them when they grasp it", ${ }^{13}$ and that in welfare policy they were not in a position to do so. The position was different in health and education, he argued: there were "large and strong spending department[s] with a tradition of reviewing activities". In the absence of such an organisation and given a broad acceptance of the existing welfare structure by both political parties there were

Commission on Social Security.) The foundation of New Zealand's modern Public Service were established following the report of the New Zealand Royal Commission of Inquiry into Unclassified Departments of the Public Service "Public Service of New Zealand" [1912] IV AJHR H-34 - usually referred to as the "Hunt Commission" after the businessman, William D Hunt, who chaired it.

11 The McCarthy Commission resumed twice, in 1968 and 1972, to review and fine tune the systems to give effect to the principle of "fair comparability".

12 See Brian Easton The Nation Builders (Auckland University Press, Auckland, 2001) and the Dictionary of New Zealand Biography (Auckland University Press, Auckland, 1998) and (Department of Internal Affairs, Wellington, 2000) vols 4-5.

13 Kenneth J Scott "Trends in Social Welfare Policies" in Kenneth J Scott (ed) Welfare in New Zealand (New Zealand Institute of Public Administration, Wellington, 1955) and (Oxford University Press, London, 1955). 
unlikely to be policy initiatives in the welfare field. ${ }^{14}$ The ACC initiative, as is discussed below, owes much to both ministers and senior officials but also, of course, to the contribution of the 1967 Royal Commission.

To some extent Scott's point about the absence of a strong bureaucratic voice with an overview of social policy remains valid for the period a decade later with which this article is concerned. At the departmental level the Social Security Department becomes the Department of Social Welfare only in 1972 as the Accident Compensation Act 1972 is passed. Extending this line nearer to the present day, it might be observed that the administration of social policy in New Zealand from the 1960s to the 1980s (and perhaps still to some extent) has suffered from problems of coordination. The Department of Social Welfare (before the restructuring of the last decade) despite some tentative attempts never exercised influence on the activity of the large spending baronies, Health and Education; Housing (in its various forms) and Maori Affairs also went their own way. The Treasury and the SSC were controllers rather than contributors to social policy formation. This was in sharp contrast to the domain of economic management where the Treasury was at least primus inter pares among departments — and most of the time rather more - and the Officials Economic Committee an effective and long-standing coordinating mechanism. ${ }^{15}$ As an example of "the lack of integrated policy in the field of income maintenance in New Zealand" Geoffrey Palmer instances the introduction of the generous Muldoon superannuation scheme in 1976. "The development of two such programmes [ACC and National Superannuation] within five years shows the extent to which income maintenance can escape rational development and respond to political pressures". ${ }^{16}$

The style of New Zealand government for most of the post-war period until the "revolution" of the 1980s was "mildly corporatist". Austin Mitchell in 1969 wrote about a "system which could perhaps be more accurately described as one of competitive group politics".${ }^{17}$ Certainly that is how it appeared to the Public Service who were attuned to successive governments whose modus vivendi was to hold the ring and maintain a balance among conflicting forces and claims. Who were the contending groups in the ACC case? Palmer in a very useful survey discusses "three powerful interest groups vitally affected by the [Royal] Commission's proposals": the insurance industry, the legal profession, and the trade union movement. ${ }^{18}$ All certainly were engaged in extended interaction with officials in the policy process.

14 Scott, above.

15 For a discussion of the operation of the Officials Economic Committee see Bernard V Galvin Policy Coordination, Public Sector and Government (Victoria University Press for the Institute of Policy Studies, Wellington, 1991).

16 Geoffrey Palmer Compensation for Incapacity: A Study of Law and Social Change in New Zealand and Australia (Oxford University Press, Wellington, 1979) 316.

17 Austin Mitchell Politics and People in New Zealand (Whitcombe and Tombs, Wellington, 1969) 33.

18 Palmer, above, 115. 
Of particular interest is the crossover between the legal profession as such and the law as represented among the Government's advisers. Apart from Woodhouse, Herbert R C Wild ${ }^{19}$ whose statement dissenting from the 1963 report of the Committee on Absolute Liability ${ }^{20}$ was influential - and John C White ${ }^{21}$ were prominent Wellington practitioners before becoming Solicitor-General. Among the Ministers Josiah R Hanan ${ }^{22}$ and John R Marshall, ${ }^{23}$ who were both solicitors, played key roles (along with Thomas $\mathrm{P} \mathrm{Shand}^{24}$ ) in promoting the development of ACC. Before the Commission itself among the many submissions by legal counsel those of the Law Faculty of Victoria University of Wellington were particularly significant. Given the influence of the legal profession on the development process, and despite the contrary direction taken by Woodhouse (see below), it is perhaps not surprising that the administration of ACC had a law reform rather than a social welfare emphasis.

The career Public Service was, however, another strong influence — although they would undoubtedly cavil at the label of "interest group" - particularly Herbert L Bockett, Secretary of Labour 1947-64, and later a member of the Woodhouse Commission, and Dr John Robson, Secretary of Justice $1960-70 .{ }^{25}$ As Palmer notes these "[p]ublic servants were concerned that New Zealand, a country which prided itself on social welfare programmes, should be a laggard in the workers' compensation field". ${ }^{26}$ Another senior official who figured prominently in the early phase of post-Woodhouse discussions was the Chairman of the Social Security Commission (1963-71), George J Brocklehurst, who made extensive submissions proposing a pension scheme to replace common-law and workers compensation to be run by the Social Security Department - a

19 Herbert R C (later Sir Richard) Wild, Solicitor-General from 1957 until appointed Chief Justice in 1965.

20 New Zealand Committee on Absolute Liability Report of Committee on Absolute Liability (Government Printer, Wellington, 1963).

21 John C (later Sir John) White, Solicitor-General from 1966 until appointed as a High Court Judge in 1970.

22 Hon Josiah R Hanan, Attorney-General and Minister of Justice 1960-69.

23 Rt Hon John R (later Sir John) Marshall, Deputy Prime Minister 1957, 1960-72, Prime Minister 1972, Attorney-General and Minister of Justice 1954-57, Attorney-General 1969-71, Minister of Labour 1969-72.

24 Hon Thomas P Shand, Minister of Labour 1963-69 (a farmer and an accountant by profession).

25 Similar roles were played by senior officials in other policy areas, for example, by Clarence E Beeby in Education, Alexander R Entrican in the Forest Service, Bernard C Ashwin in the Treasury, and Alister D McIntosh in External Affairs. All were appointed at a young age while the first Labour Government was in office and remained for periods approaching and some exceeding 20 years.

26 Geoffrey Palmer Compensation for Incapacity: A Study of Law and Social Change in New Zealand and Australia (Oxford University Press, Wellington, 1979) 69. 
proposition which, despite a measure of support from Woodhouse and the "Commentary"27 fell out of the discussion as the scheme began to take legislative form.

\section{MACHINERY OF GOVERNMENT ISSUES}

Machinery of government issues did not figure prominently in any of the published documents. Nor does there appear to have been any structured discussion at the official level of the policy issues discussed below. By contrast a great number of public service hours were invested in "administration" in the sense of making the scheme work (as is also discussed later).

\section{A Welfare or Law Reform?}

The thoughts of Woodhouse on administration of the proposed scheme were brief and guided by the Commission's philosophy that the aim was "a unified and comprehensive scheme of accident prevention, rehabilitation, and compensation". While acknowledging that "the scheme outlined involves a partial merger with some aspects of the social security system" the Commission recommended that the scheme "should be brought to life and set upon its course by an independent authority whose whole responsibility it would be to ensure the successful application of [the] general philosophy". Clearly the attention to be given to accident prevention and rehabilitation was influential. The authority was, however, to "operate within the general responsibility of the Minister of Social Security and be attached to his Department for administrative purposes". 28

The Commission reported in December 1967. On 20 May 1968 the Government established an interdepartmental committee (IDC) chaired by the Secretary of Labour (Noel R Woods) and including the Solicitor-General (John White), the Social Security Commission (George J Brocklehurst) and the Treasury (Ross R Carroll). ${ }^{29}$ The committee's brief was to examine feasibility of a scheme and "any foreseeable problems or difficulties". The relationship between the new scheme and social security was high on the committee's agenda. The Social Security Department was concerned from the outset about "the evolving of a separate, major and more generous social security scheme for injury based on different principles from the basic social security scheme". ${ }^{30} \mathrm{In}$ a memorandum of 26 July 1968 to the interdepartmental committee Brocklehurst said: ${ }^{31}$

27 "Personal Injury: A Commentary on the Report of the Royal Commission of Inquiry into Compensation for Personal Injury in New Zealand" [1969] IV AJHR H 50 ["Commentary"].

28 New Zealand Royal Commission of Inquiry into Compensation for Personal Injury Compensation for Personal Injury in New Zealand: Report of the Royal Commission of Inquiry (Government Printer, Wellington, 1967) 307.

29 Cabinet Minute (20 May 1968) 18/8/88.

30 George J Brocklehurst to Minister of Social Security (1 March 1968). Copy on Treasury File T40/470/1 (Archives New Zealand W2591).

31 George J Brocklehurst, to Interdepartmental Committee (26 July 1968). Copy on Treasury File T40/470/1 (Archives New Zealand W 2591). 
The department would wholeheartedly support any unified system of provision for incapacity which replaces the overlapping compensation of the present remedies now available ... It is agreed that the Social Security Department is the most appropriate to administer a system of injury benefits if only for the reason of interrelationship in the distribution of benefits and for economies in administration ... There would appear to be no insupportable difficulties in the establishment of a national monopoly and the appropriate administration to go with it if the framework is to lie with the Social Security Department.

In a fascinating paper provided to the interdepartmental committee, Social Security crafted a discussion around the issues in the form of a "Socratic dialogue heavily used in the Greece of Pericles and as recently as the eighteenth century by Berkeley for written philosophical debate". The debate was between for, "a reasonable (not necessarily rational) man who gave his overall support to the scheme ... Although he has considerable insight into the whys and wherefores of the scheme he is not a government nor a departmental man" and against, who "gives full vent in emotional and rational reactions to the suggestions of the scheme put forward by FOR". Despite the arguments put forward by Social Security the interdepartmental committee report was inconclusive on the administrative location (as on other issues) - perhaps because of pressure from the caucus committee also considering the Woodhouse report that officials should complete their report to a deadline. ${ }^{32}$ To the extent that the draft report seemed to envisage a degree of independence from departments the Treasury took exception: ${ }^{33}$

In Treasury's understanding all the Committee's discussions up to this stage have been on the assumption that the administration of the scheme would be under the general jurisdiction of the Social Security Department, and no justification can be seen for setting up an entirely independent authority.

On 8 April 1969 Cabinet agreed that the Government should draft a "White Paper" hereinafter referred as the "Commentary" - without commitment. $^{34}$ On machinery of government

32 In a file note of 3 December 1968 (copy on Treasury File T40/470/1) Noel R Woods conveys the Minister's instruction that the interdepartmental committee report is to be available promptly to the caucus committee.

33 Ross Carroll to the interdepartmental committee 7 January 1969 (Treasury File T40/470/1). Treasury's position throughout the ACC establishment process can be described not unfairly as a "watching brief". Ross Carroll was an experienced Divisional Director but from the files he seemed to reflect a Treasury position that so long as there was no direct cost to the revenue - for benefits, administration, or to the state as an employer - the Treasury should not oppose. The Secretary (1968-76), Henry G Lang, was concerned that ACC payments should be taxable and was asked to appear personally before the caucus committee but there is no evidence that he did. Nor did the Treasury make submissions to the Gair Committee (Labour, Social Security, Justice, and Health made submissions "generally in favour", and Inland Revenue and Transport on specialised issues (Geoffrey Palmer Compensation for Incapacity: A Study of Law and Social Change in New Zealand and Australia (Oxford University Press, Wellington, 1979)).

34 "Personal Injury: A Commentary on the Report of the Royal Commission of Inquiry into Compensation in New Zealand" [1969] IV AJHR H 50 ["Commentary"]. 
matters the "Commentary" noted that "the Commission chose instead [of a public/private option] to create a new institution in the form of the authority and to use the existing Social Security Department to assist the authority to carry out its functions". ${ }^{35}$ It went on to note that the authority must be linked with its main servicing department at a level and in such a way that will ensure to the department a proper say in the discharge of the responsibilities that it will be carrying out for the authority. ${ }^{36}$ And later, almost incidentally, in a discussion of the relationship between the new body and a range of agencies, "[t]he responsibilities of the Social Security Department will be increased as it will be the main payment and servicing organization assisting the authority". ${ }^{37}$ By the end of the "Commentary" it is, however, beyond doubt that the Social Security Department is assumed to be "the main servicing agent". ${ }^{38}$

Just before the 1969 General Election the "Commentary" was referred by Parliament to an ad hoc select committee ("the Gair Committee"), which reported in October 1970. On substantive policy matters this committee was clearly crucial. On the nature of administrative responsibility for the recommended scheme it confined itself to saying that "[t]he prime responsibility for administration of the compensation matters will lie with a new statutory authority ... [which] will comprise three Commissioners and the necessary staff and will have the degree of independence proposed by the Royal Commission." Recognising that the role of insurance companies remained an open question (and not favouring compensation business being placed as a monopoly with the State Insurance Office (SIO)), the Select Committee referred to a choice to be made between the authority having its own staff or being serviced by the Social Security Department if insurance companies were not to be involved. The links to Social Security were still alive - but only just. ${ }^{39}$

By 1970 there was a clear shift in the thinking of the National Government away from setting the Woodhouse proposals in a social welfare context. Palmer quotes an undated Labour Department memorandum "strongly opposed" to Social Security responsibility: ${ }^{40}$

This proposal is a proposal of insurance. As insurance it would be accepted by a great many people who would have a substantial objection to extension of the Social Security system and Social Security principles into this field.

35 "Commentary", above, para 278 (emphasis added).

36 "Commentary", above, para 281.

37 "Commentary", above, para 286 (emphasis added).

38 "Commentary", above, para 310.

39 Select Committee on Compensation for Personal Injury in New Zealand "Report of Select Committee on Compensation for Personal Injury in New Zealand" [1970] AJHR I 15.

40 Quoted in Geoffrey Palmer Compensation for Incapacity: A Study of Law and Social Change in New Zealand and Australia (Oxford University Press, Wellington, 1979) 77. 
Before the select committee there was strong criticism on behalf of a Railways union of any suggestion that the scheme would be administered by Social Security. And one Member of Parliament (a supporter of Woodhouse) regarded "this social security business" as a "red herring". ${ }^{41}$ The emphasis of Woodhouse on the prevention function, in which the Department of Labour had the principal (but not exclusive) role, was probably also a factor. Furthermore, the future shape of the social security system was itself now the subject of inquiry by a Royal Commission. Whatever the reasons, the 1971 Cabinet Committee on Compensation for Personal Injury and its advisers, the Interdepartmental Committee on Compensation - the "Perry Committee"42 - seem to have proceeded on the basis that the new independent body would operate outside the social security arrangements. (Social Security was not a permanent member of the Perry Committee.) Increasingly the scheme was being portrayed principally as a matter of law reform.

\section{B Decentralisation}

Apart from any broad policy considerations, the question which seemed to be crucial in determining a "home" for the new authority was "whether the scheme is to be administered centrally as in Ontario, or, if not, the extent to which it should be run on a decentralised basis". ${ }^{43}$ The differences between Ontario and New Zealand were highlighted but significantly the "Commentary" opined that "[d]ealing by mail with an abstract entity in Wellington may not be acceptable in the New Zealand environment". ${ }^{4}$ This, it will be recalled, was a time when most government departments had an extensive and hierarchical network of regional and district offices throughout the country.

The claimed advantages of a decentralised form of administration underpinned the working assumption in the "Commentary" that local offices of Social Security (by 1974 numbering 29 in major centres and 19 in smaller towns) would not only act as recipients of claims but would also "be in a position to learn about any particular personal problems an individual claimant might have relating to their injury, treatment or compensation". ${ }^{45}$ In Ontario "reliance on the concentration of

41 Palmer, above, 93.

42 Andrew R Perry LLB had recently been appointed Deputy Secretary of Labour, after a lengthy period as Secretary to the Cabinet; he was formerly a senior officer of the Department of External Affairs. Others on the committee were George S Orr, Deputy Chairman, SSC (and later Secretary of Justice), Ross R Carroll (Divisional Director, Treasury), A J Edwards, Deputy Secretary of Transport), and Bruce J Cameron (Assistant Secretary, Justice). J G Hamilton, a very experienced member of the Law Drafting Office, was responsible for the prolonged exercise of translating the new scheme into statute. The committee met throughout 1971 and 1972.

43 "Personal Injury: A Commentary on the Report of the Royal Commission of Inquiry into Compensation in New Zealand", [1969] IV AJHR H 50 ["Commentary"].

44 "Commentary", above.

45 "Commentary", above, para 301. 
computer processing in head office is regarded as an essential feature of the highly centralised system". But the "Commentary" was confident that "it is now possible to combine the benefits of a centralised computer operation with the benefits of partial decentralisation, although this might be more costly than total centralisation". These were still the early days of computerisation: only in 1972 was the Computer Services Division brought within the State Services Commission. ${ }^{46}$

Overshadowing the place of Social Security was the role to be played by the insurance companies. If, contrary to the proposals of Woodhouse and the "Commentary", they were to act as agents of the new authority, the functions of either Social Security or a new network of compensation offices would be reduced. The Gair Committee and the National Government (through the passage of the 1972 Act until electoral defeat at the end of 1972) kept the door open for the insurance companies and it was the newly-established Accident Compensation Commission that in March 1973 recommended to the Kirk Government that "in the initial stages" the State Insurance Office (SIO) should be the sole agent for receiving claims under the new scheme. ${ }^{47}$

The procedures followed by the SIO are well summarised by Ison. ${ }^{48}$ While straightforward claims could be dealt with by the SIO a wide range of claims were referred to ACC Head Office. In Ison's view, "[a] serious problem with this structure is that it can deny procedural due process". He also comments "that there may be some difficulty in reconciling, within the same management structure, the social service objectives of the ACC with the profit objectives of the SIO". ${ }^{49}$ As early as 1980 the decision-making authority of the regional offices opened in 1976 was being extended, and a "pilot" branch office had been established in Dunedin. ${ }^{50}$

Whether or not the administrative efficiency and client responsiveness of the ACC would have been enhanced if the originally proposed links with Social Welfare (formerly Social Security) had been maintained is a question that invites speculation. Palmer suggests that a Social Security estimate of 600 additional staff frightened the Gair Committee but notes that by 1978 the ACC had almost 500 staff and the SIO had recruited an additional 100 staff. $^{51}$ Palmer also concludes, "in retrospect an ordinary department of state would have been better, as long as benefits were defined with clarity and insulated from all possibility of political or ministerial direction in the

46 The Treasury purchased the first computer in the 1950s; for a brief period centralised services were under the Department of Internal Affairs.

47 State Insurance Office to State Services Commission (22 March 1973) SSC File SSC11/1/10/1 (Archives New Zealand W2702).

48 Terence G Ison Accident Compensation (Croom Helm, London, 1980) 80-89.

49 Ison, above, 89.

50 Ison, above, 90 .

51 Geoffrey Palmer Compensation for Incapacity: A Study of Law and Social Change in New Zealand and Australia (Oxford University Press, Wellington, 1979) 382. 
determination of claims".52 This judgment was perhaps as much influenced by constitutional considerations of ministerial responsibility and public accountability as a calculation of possible efficiency gains.

\section{The ACC Quango}

Polaschek in 1958 regarded "the proper sphere of the public corporation as opposed to the department of State" as one of the "big questions" of New Zealand public administration. ${ }^{53} \mathrm{He}$ noted that for all New Zealand's experience with non-departmental forms of organisation "New Zealanders have not speculated much on the place that they might advantageously occupy in government. Neither have they followed ascertainable principles in deciding when to set up a corporation or company instead of the 'customary' department". ${ }^{54}$ The ACC experience would not have altered that judgment.

"Independence" was the cornerstone of the proposed Woodhouse arrangements. The "Commentary" said: 55

There are two conflicting aims involved in the management of the Commission's scheme. The authority must be independent of the Government of the day in the exercise of its wide discretionary powers. On the other hand the very wide range of duties encompassed in the scheme requires public accountability for the broad administration of the scheme and for the adequacy of the legislation under which the authority operates. It appears that there are several bodies whose statutory organisation might constitute a precedent for the resolution of the conflicting requirements of the independence of the authority in its administration of the legislation and the responsibility of a minister to Parliament.

As noted earlier, the Gair Committee had little to say about these matters and broadly supported the "degree of independence" proposed by Woodhouse. Hansard likewise records little parliamentary interest. C C A McLachlan, Chairman of the second select committee (that considered the Accident Compensation Bill) simply observed that the committee had sought "to avoid the unnecessary establishment of a new top-heavy organisation". 56

There is little evidence in the departmental files that the institutional provisions of the 1972 Act in this area were controversial. Apart from the standard sections requiring the presentation to the

52 Palmer, above.

53 Raymond J Polaschek Government Administration in New Zealand (New Zealand Institute of Public Administration, Wellington, 1958); (Oxford University Press, London, 1958) 56.

54 Polaschek, above.

55 "Personal Injury: A Commentary on the Report of the Royal Commission of Inquiry into Compensation for Personal Injury in New Zealand" [1969] IV AJHR H 50, para 281 ["Commentary"].

56 C C A McLachlan MP (3 October 1972) 381 NZPD 2993. 
House of Representatives of an annual report and audited accounts, there was also section 20 requiring the Commission "to give effect to the policy of the government in relation to those functions and powers as communicated to it from time to time in writing by the Minister". In early drafting this read "to have regard to ...". Of more contention was the draft provision requiring salaries and conditions of the Commission's staff to be determined "in agreement" with the SSC. It was argued that the expression "in consultation with" had "proved unsatisfactory in the past". ${ }^{57}$ Ministers asked for this to be reconsidered: they had "some reservations ... because this [agreement] implied that the State Services Commission would fix the salaries of officials of the Accident Compensation Commission". "With the concurrence of" was agreed upon. ${ }^{58}$

In the event, the SSC view seems to have prevailed; section 24C of the 1972 Act provided that salaries and allowances were to be set within "scales fixed by the Accident Compensation Commission in agreement with the State Services Commission or by the Minister in the absence of agreement".

\section{Ministerial Responsibility}

A point that is worthy of recording is the statutory location of agency responsibility for the administration of the Accident Compensation Commission Act 1972. In the principal Act the notation is that "This act is administered in the Department of Labour". In the 1975 Reprinted New Zealand Statutes ${ }^{59}$ the Department of Labour was replaced by the Accident Compensation Commission.

The Minister of Labour, however, remained the responsible Minister throughout. (Palmer attributes this to the historical accident of Thomas P Shand, as Minister of Labour, being the initial advocate within the government). ${ }^{60}$ This immediately raises the question of responsibility to Parliament for the new Commission. Initially — prior to the 1973 inclusion of the non-earners' scheme - the ACC required no contribution by the taxpayer. Parliamentary accountability through an opportunity for debate in the House was provided by the inclusion of an amount for the chairman's salary under Vote Labour. When the non-earners' scheme was introduced in 1973 a significant contribution from the Consolidated Revenue Account was required to fund the Supplementary Fund. This was found in Vote Social Welfare Programme II: Monetary Benefits. The result is the unusual (but not unique) situation that a minister was responsible for the

57 (21 September 1971) CPI(71)M6.

$58 \quad$ (12 November 1971) CPI(71)M4.

59 Reprinted New Zealand Statutes (1975) Vol 2 1409-1657.

60 Geoffrey Palmer Compensation for Incapacity: A Study of Law and Social Change in New Zealand and Australia (Oxford University Press, Wellington, 1979) 383. 
expenditure of funds from the Vote of another minister, a situation that the Treasury at least, some years later, found uncomfortable. ${ }^{61}$

No control is exercised over that expenditure, or over related policy matters, by the Department of Social Welfare. It points out that it has neither the staff, resources, nor the expertise, to act as an adviser to Government in respect of the Accident Compensation Commission. It also notes that its Minister has no responsibility for the Commission.

The Accident Compensation Commission Act provides that the Minister of Labour is the Minister in Charge of the Commission and he is formally responsible for the Commission, both in Parliament and Cabinet. However, his Department has only limited involvement with the Commission (in the area of industrial safety) and is unable to provide the Minister with any independent advice on the Commission's wider activities.

The present position is, therefore, one in which no agency of government has either the resources or the responsibility for providing independent advice or policy and financial issues arising out of the activities of the Accident Compensation Commission. Treasury exercises some overview in the course of its responsibilities towards Vote Social Welfare. However, if no one is aware of the need to refer financial matters to Treasury, even that overview is not available.

The Treasury argued that the Vote and ministerial responsibility should be brought together and set out various arguments for and against Social Welfare and Labour respectively. The Minister of Finance referred the report to the Cabinet and the funding provision was transferred to Vote Labour from 1980/1981.

Ison provides an outsider's view: ${ }^{62}$

One handicap in the rational development of the system is the lack of a portfolio into which the ministerial responsibility for the ACC will neatly fit. The Minister of Labour is responsible for ministerial functions in relation to the ACC, but that tends to be a crisis portfolio. A Minister of Labour is usually pressed to spend his time on the bush fires of labour relations rather than undertaking the contemplation necessary for system reform in areas for which there is no appearance of urgency. The Ministry of Social Welfare has sometimes been mooted as a more appropriate portfolio, but any transfer of ministerial responsibility there might create a risk of individual needs and floor-level income support coming more into focus, with a consequential loss of the role of the state in administering income insurance beyond floor level.

The ACC was established in accordance with the statutory template that with variations applied to other non-departmental bodies. On the one hand, dealings with individual citizens were beyond

61 Treasury to Minister of Finance (14 January 1980) File T40/470/1 (Archives NZ W2591).

62 Terence G Ison Accident Compensation (Crown Helm, London, 1980) 188. 
ministerial intervention. On the other, there was the capacity in the statute for the government of the day to play the deciding role in such important specific matters as levy rates and maximum amounts of compensation (section 15) and generally to require the ACC "to give effect to the policy of the government in relation to those functions and powers as communicated to it from time to time in writing by the Minister" (section 20). There is, however, an important question that can only be answered by those who have a close acquaintance with the way in which the relationship between the Commission and ministers evolved over the next 30 years. That is the degree to which "independence" was exercised. Palmer in 1979 was of the view that the Commission's "independence from Government is more apparent than real". 63 Nonetheless it is clear that in the first decade both politicians and the central agencies were less than enamoured of the ACC's performance - and for the officials at least the Commission's distance from the core Public Service was a factor in this dissatisfaction.

\section{THE ESTABLISHMENT CHALLENGE}

The SSC in commenting on the remuneration to be paid to the new Commissioners acknowledged that they were to be responsible for a "vast undertaking of establishing a major new public corporation starting virtually without accommodation, established procedures, handbooks, experienced staff etc". ${ }^{64}$ A perusal of departmental files provides ample confirmation of that statement. It also supports the observations made by ministers in the House, and by outside observers at the time, that the Public Service displayed great industry and dedication in tackling this large administrative task. Dr A M Findlay, Opposition spokesman on ACC, on the third reading of the Bill spoke of "the dedicated assistance on the part of officials", singling out Perry in particular, and cited an American professor who "expressed amazement at the amount of work we expected to get and received from higher public servants". ${ }^{65}$

The Labour Department was at the centre of the service-wide official preparation for the establishment of the ACC. In October 1970 it expressed the view (in a draft cabinet paper) that "So far as can be seen ... the Select Committee's report does not raise legislative or administrative problems that cannot be resolved in the normal way". 66 The "normal way" was an interdepartmental committee chaired by Labour - it met first on 21 December 1970 under the chairmanship of E G Davey, Secretary of Labour - and comprised representatives of the Treasury, SSC, the Department of Justice and the Ministry of Transport. Very quickly a series of working parties was set up to prepare operating procedures that could be in place by 1 October 1973. A number of

63 Palmer, above, 383.

64 SSC to Chairman, Cabinet Committee on State Services (25 September 1972) SSC File SSC3/6/33 (Archives NZ W3005).

65 Dr A M Findlay, MP (30 October 1972) 380 NZPD 2250.

66 Copy on Treasury file T40/470/1 (Archives NZ W2591). 
retired senior public servants were recruited to assist: L M Graham (former Assistant DirectorGeneral of Education, later ACC Commissioner), B C Magill (former Assistant Commissioner of Works) and G Armstrong (formerly solicitor, Public Trust Office). ${ }^{67}$ The range of issues to be considered and the number of departments involved was very extensive. Forms were drafted, manuals prepared, accounting procedures defined. At the same time the IDC was considering the policy issues on which Cabinet direction (through the Cabinet Committee on Accident Compensation - chaired by the Minister of Labour, initially John R Marshall and then D S Thomson) was necessary before legislation was ready for introduction into the House.

In the event an incomplete Bill was introduced on 15 December 1971 - 29 further clauses were added by supplementary order papers while the Select Committee was considering the Bill. The IDC officials (principally A R Perry and his Labour colleagues) provided advice to the Committee. The Act was passed on October 1972 just prior to the November General Election in which Labour led by Norman Kirk defeated the National Government of John R Marshall. At that point the Accident Compensation Commission becomes the principal adviser to the Government ${ }^{68}$ although the Treasury continued to advise against the inclusion of non-earners (funding for which, by annual appropriation from the Consolidated Revenue Account, was not determined until 10 September 1973). ${ }^{69}$

Several issues deserve further attention. The first is the delay in the inauguration of the scheme. The working assumption of officials had been 1 October 1973. This was always regarded as tight. For example, an SSC file note acknowledges that "[a] close watch will have to be kept on progress so that if necessary the Commission can assist the Labour Department in a "salvage operation" to meet the deadlines."70 Two months after their appointment the new Commissioners wrote to the minister (H Watt) saying that they had: ${ }^{71}$

67 Armstrong had responsibility, at least in the early stages assisted by B Banks (later Crown Counsel), of Labour for the drafting of legislation.

68 The first Commissioners, K L Sandford (a Hamilton solicitor), J L Fahy (Regional Controller, Auckland, IRD, and A R Perry (understood to be a temporary appointment "in view of the fact that it had not been possible, in the time available, to obtain the services of an accountant from the private sector" and later replaced by L M Graham) were invited by National (27 November 1972, CM 72/48/31) and their appointments confirmed by Labour (20 December 1972, CM 72/53/11).

$69 \mathrm{CM} 73 / 42 / 14$. In an internal note to Assistant Secretary J D Lang, Carroll, the Treasury's officer principally concerned with ACC from the outset, notes "[t]he attached cabinet minute indicates that there are going to be difficulties with the new Government in maintaining the previously accepted principle that the Accident Compensation Commission should be self-financing on a fully funded basis".

70 A C Davis (2 June 1972) SSC 3/6/33 (Archives NZ W3005).

71 Sandford to Minister (22 February 1973). Copy on Treasury File T40/470/1 (Archives NZ W2591). 
regretfully, but not unanimously, concluded that the compensation schemes cannot be introduced on 1 October 1973 ... [W] have not only considered the physical possibility of commencing on that date, but have also regarded it as important that the schemes should be able to begin in an atmosphere of administrative efficiency, to a level acceptable not only to Government, but perhaps more importantly to injured persons and the public generally.

Among the matters that concerned the Commission were: the absence of any permanent senior staff — the response to advertising for six directors had been "extremely disappointing" the question — of appointment of agents remained unresolved, ${ }^{72}$ the Commission was studying in depth the rating question, legislative amendments (for instance, on the definition of "personal injury by accident") were necessary, and fees payable to the medical profession were still being negotiated. The proposed date of 1 April 1974 was accepted by the Government.

Recruitment of senior staff was clearly a problem for the new Commission. The appointment of a Medical Director was of considerable importance and the New Zealand Medical Association (NZMA) took a close interest. The Chairman of the NZMA Council was the redoubtable Dr (later Sir) Randal Elliott who conveyed to the Minister the view that a substantially higher salary than was on offer was going to be required. The Minister, because of the need to maintain relativity with departmental and hospital doctors, could only reply that he felt "that from a practical viewpoint, the Commission would not be able to offer a salary matching, or even approaching the income of a highly successful distinguished doctor in private practice". Sandford in submitting a draft reply to the minister conceded that he believed that there was "some validity" in the point made by Dr Elliott. ${ }^{73}$ This was a period marked by double figure inflation, constraints such as the Stabilisation of Remuneration Regulations, and a persistent claim that the state sector was "leading" pay increases. The problem of recruitment of professional staff was common across the state sector.

One issue decided, but not without argument, was where the head office of the new commission should be. The Chairman of the SSC (IG Lythgoe) personally held a strong view that the ACC should be established in Christchurch. Writing to the Chairman of the Cabinet Committee on State Services on 30 June 1972, Lythgoe said: ${ }^{74}$

The Commission has found that once an organisation is established in Wellington it is difficult to transfer because of its entrenched position; it has established relations with other bodies; staff have purchased homes; and very good reasons are advanced for staying in Wellington.

72 Among other considerations, the ACC mentioned the criticism that appointment of the SIO in a monopoly position would give that organisation an unfair advantage in other fields of insurance. The Treasury copy has the marginal comment by the Minister of Finance, Wallace (Bill) E Rowling: "so what!" T 40/470/1 (Archives NZ W2591).

73 AACT 62 Box 1A Ministerial Correspondence 1973-76 (Archives NZ AACT 62 Box 1A).

74 SSC File 3/6/33 (Archives NZ W3005). 
Perry expressed "grave reservations" and Lythgoe accepted that the high policy content of the ACC's work in the establishment phase could justify a Wellington headquarters but that Christchurch might later be considered for processing. On behalf of the yet to be established Accident Compensation Commission, the Government Accommodation Board (a branch of the $\mathrm{SSC}$ ) proceeded to lease space in Feltex House, Sturdee Street, Wellington.

A corollary of the introduction of ACC (and an exercise proceeding in parallel with establishment of the Commission itself) was the consequential change for the Government as an employer. ${ }^{75}$ From February 1972 a Joint State Services Coordinating Committee/Combined State Services Organisation (SSCC/CSSO) working party laboured over the myriad of amendments needed in state sector conditions of employment and such matters as insurance cover on official travel that were the responsibility of the Treasury (and recorded in the Treasury Instructions). The 140 occupational classes in the Public Service coupled with the particular conditions applying to Railways, Post Office, Ministry of Works and New Zealand Forest Service wage workers made this a complex and time-consuming exercise. The files suggest that, unlike concurrent disputes over state sector pay, relations between the employing authorities and the state unions over ACC matters were relatively amicable. The atmosphere was no doubt assisted by the unions' strong support for the Woodhouse proposals. ${ }^{76}$

Despite the early difficulties of recruitment within the bounds set by relativity of pay scales with the Public Service, Campbell judges that: ${ }^{77}$

in the early days the morale of the staff was very high, as they considered themselves privileged to be taking part in such an innovative experiment. Over time, however, disenchantment set in, and much of this must be laid at the door of the commissioners.

Whatever the reason, there is the purported evidence of a joint ACC/SSC management audit carried out at the request of the Government in 1978. In the words of the Chairman of the Labour and Education Select Committee (A G Malcolm) reporting back to the House in 1980 the Bill replacing the Commission by a Corporation: ${ }^{78}$

The State Services Commission said that there was a complete lack of internal communication in the Accident Compensation Commission, that there was total confusion between administration and policy,

75 Apart from the Treasury, there was no dissent from the proposition that the Crown should be bound by the ACC legislation. The Treasury favoured the Crown continuing to carry its own risk.

76 The Public Service Association (PSA) registered minor key objections to the establishment of the ACC outside the public service but did not press the issue (PSA Newsletter (29 March 1972).

77 Ian Campbell Compensation for Personal Injury in New Zealand: Its Rise and Fall (Auckland University Press, Auckland, 1996) 48.

78 Quoted by Campbell, above, 53. Campbell asserts that "it was certainly not correct to state that the commissioners did not speak to each other". 
that the internal structure was such that various divisions reported to separate commissioners who often did not speak to each other, which has led to internal separation of divisions, a lack of liaison, in the commission, and poor staff relationships ... I make no bones about the fact that the Government is putting a stick of dynamite under the top management structure.

\section{CONCLUSION}

It is now possible to offer some tentative conclusions on the themes set out at the beginning of this article:

Was there adequate preparation for the ACC by the "old" Public Service? The judgment at the time was favourable at least in terms of dedicated effort. Reading the files leads to the conclusion that the ACC establishment was an illustration of what the Public Service in its heyday was good at. There was a high degree of cooperation among departments to put in place the Government's policy. A vast amount of experience and expertise was devoted by the senior Public Service to resolve difficult policy issues and to enable the new Commission (when formed) to have the foundation of operational systems. The delay from 1 October 1973 to 1 April 1974 does not invalidate this conclusion.

Was the ACC in its early years something of a "bureaucratic orphan"? There is no question but that the Department of Labour ushered the Commission into existence in a diligent and committed manner. Between 1972 and 1975 Labour lost its status as the agency formally charged with the administration of the Accident Compensation Act 1972. With Perry temporarily and then Graham as commissioners the institutional memory of the Department of Labour may be presumed to have passed to the ACC. Certainly there is no indication that Labour saw itself as being "responsible" for the Commission or ACC policy. Social Welfare was clearly taken out of any principal role after the 1970 Gair Committee even though the appropriation for the supplementary fund was on Vote Social Welfare from 1974/1975. Equally, there is some evidence to support the suggestion that the Commission was, not surprisingly, jealous of its independence; this sensitivity was matched by a certain distancing of the SSC and the Treasury from the new Commission.

Was there some sense of alienation on the part of the control agencies? The State Services Commission (SSC) played a generally benign role in the establishment process but points of tension can be discerned, particularly in the SSC's role in pay fixing and exchanges over accommodation and remuneration of commissioners. The Treasury was from the outset focused on the objective which was lost - that there should be no charge on the Consolidated Revenue account. It also sought successfully a position of influence in the investment of the ACC funds. ${ }^{79}$ The initiative for acceptance in the institutional family would need to come from the new Commission.

79 The Treasury also thought that the ACC would need its own actuarial advice "but the Commission tends to be a bit sensitive over such matters" (Ross Carroll to J D Lang (28 March 1973) T 40/470/1 (Archives NZ W2591)). 
Are there lessons to be learned from the machinery of government choices made, notably the establishment of the ACC as a quango rather than within the departmental framework? In retrospect it seems that there was surprisingly little rigorous analysis devoted to these issues. Given the conviction on the part of ministers that ACC was a law reform rather than a social policy initiative the move away from Social Welfare as the "parent" department was understandable. But other departments did not have the national network and payments experience of Social Welfare offices. It is tempting to think that the early years of the scheme might have been smoother if there had been a closer association with a department. "Hiving off" the scheme into a public corporation or, in current terminology, a Crown entity could have constituted a second phase. Certainly the arrangements established for ministerial responsibility and public accountability were not particularly coherent but the experience of the past few years with Crown entities (such as the Tourism Advisory Board, the Lotteries Commission and the Fire Services Council) suggests that the ideal model has not yet been found ${ }^{80}$ The extent to which other administrative paths might have been followed with advantage is perhaps a question to which those with greater experience of later decades might attempt an answer.

80 For a discussion of the confused accountability arrangements for Crown entities see Controller and AuditorGeneral Governance Issues in Crown Entities (Government Printer, Wellington, 1996). 